\title{
Potential of Using Kitchen Waste in a Biogas Plant
}

\author{
A. Apte, V. Cheernam, M. Kamat, S. Kamat, P. Kashikar, and H. Jeswani
}

\begin{abstract}
India's economic growth is contributing to a massive increase in the generation of solid waste. Approximately 55 million tones of Municipal Solid Waste is generated annually by urban areas in India. Over 59\% of homes in urban India use Liquified Petroleum Gas (LPG) supplied in portable cylinders for their cooking needs. However, due to our country's dwindling petroleum reserves and increased costly imports of petroleum, non conventional energy resources are slowly gaining importance. The use of biogas using kitchen waste as feedstock can help solve the problem of energy deficit and at the same time, allow the safe disposal of kitchen waste which is often unscientifically dumped or discarded. Our institute campus (Bhavans' campus) has a number of campus kitchens that utilize several LPG cylinders and also generate large amounts of kitchen waste. The kitchen waste generated has high calorific value and moisture content; hence it can be anaerobically digested. The biogas produced can be used to supplement the fuel requirements of the campus kitchens that generate the kitchen waste. This study consists of carrying out survey, characterization of kitchen waste from several kitchens and exploring it's potential to be used for biogas production.
\end{abstract}

Index Terms-Biogas, municipal solid waste, kitchen waste, calorific value.

\section{INTRODUCTION}

Municipal Solid Waste (MSW) is defined as any waste generated by household, commercial and/or institutional activities and is not hazardous [1]. With rapid urbanization, the quantities of municipal solid waste, an important by-product of an urban lifestyle, is increasing at a rate faster than urbanization itself. In India, ten years ago, there were 2.9 billion urban residents, each generating 0.64 $\mathrm{kg} / \mathrm{capita} /$ day of MSW. Today, there are about 3 billion residents generating $1.2 \mathrm{~kg} / \mathrm{capita} / \mathrm{day}$. It is estimated that by 2025 , these numbers will increase to 4.3 billion urban residents with $1.42 \mathrm{~kg} / \mathrm{capita} /$ day of MSW [2]. Waste generation is directly related to the economy of a country. There can be variations in the generation rates within a country, and even within the same city. Industrial countries account for a large portion of the world's MSW relative to their share of world population, while developing countries give a large portion of MSW relative to their share of world income. Classification of the regions of the world based on their affluence provides a more organized outlook to waste

Manuscript recevied January 10, 2013; revised April 4, 2013. This work was supported in part by the TEQIP Phase II

A. Apte, V. Cheernam, M. Kamat, S. Kamat, and P. Kashikar are with Sardar Patel College of Engineering, Affliated to Mumbai University, Andheri (W), Mumbai, India.

H. Jeswani is with Civil Engineering Department Sardar Patel College of Engineering, Andheri (W), Mumbai, India (e-mail: hansajeswani@gmail.com). generation rates and waste management practices. The World Bank has classified the 188 World Bank member countries based on the Gross National Income per capita (GNI) [3]. It's evident for Table I that the high income countries produce more waste per capita as compared to the low income countries.

TABLE I: WASTE GENERATION RATES

\begin{tabular}{lc}
\hline \hline Income Level & Waste generation (kg/capita/day) \\
\hline High & $0.7-14$ \\
Upper Middle & $0.11-5.5$ \\
Lower Middle & $0.16-5.3$ \\
Lower & $0.09-4.3$ \\
\hline \hline
\end{tabular}

There is a country-wise classification of economies into the upper, middle and lower incomes. However, in a single country itself, the affluence varies among the population. For e.g., in India and China, there is disproportionately high urban waste generation per capita relative to overall economic status. This is because they have very high poor rural populations that dilute their economic status [4].

Solid Waste Management (SWM) is an organized process of storage, collection, transportation, processing and disposal of solid refuse residuals in an engineered sanitary landfill. It is an integrated process comprising several collection methods, varied transportation equipments, storage, recovery mechanisms for recyclable material, reduction of waste volume and quantity by methods such as composting, waste-to-power and disposal in a designated engineered sanitary landfill [5]. A major part of MSW is generated from urban areas i.e. cities and bigger towns. India is primarily a country with a huge rural population. However, it is estimated that about $40 \%$ of the Indian population will move towards urban areas by 2026. Currently, an estimated 48 million tonnes of solid waste and 4,400 million cubic meters of liquid waste are generated every year in the urban areas of the country. As per the study of "National Master Plan for Development of Waste to Energy in India", 17 (6\%) cities have generation rate in excess of 1000 TPD, 80 (26\%) cities generate between 150-1000 TPD and balance 202 (68\%) cities generate less than $150 \mathrm{TPD}$. The MSW ranges from $250 \mathrm{gm}$ to $700 \mathrm{gm}$ per day per person with an average of 490 gm per day per person [6].

A study conducted by the Central Pollution Control Board (CPCB) on MSW management in India shows that waste generation is estimated to increase rapidly at present from 490 gm per person per day to 945 gm per person per day which would result in 300 million tonnes per year from 48 million tonnes per year by the year 2047 .

To tackle the yearly 5\% increase of waste in urban India, urban local bodies are investing around $35-50 \%$ of its available funds yearly, spending about Rs. 500-1500 per ton on solid waste management. In view of growing challenge, 
Central Government has incorporated solid waste management as one of the components in Jawaharlal Nehru National Urban Renewal Mission (JNNURM) for extending financial resources. As observed from Table II, of 62 cities are covered under this mission with total investment of US\$20 billion in 7 years [7]. MSW contains compostable organic matter (fruit and vegetable peels, food waste), recyclables (paper, plastic, glass, metals, etc.), toxic substances (paints, pesticides, used batteries, medicines), and soiled waste (blood stained cotton, sanitary napkins, disposable syringes).

TABLE II: WASTE GENERATION RATES IN INDIA

\begin{tabular}{lc}
\hline \hline Population & $\begin{array}{c}\text { Waste Generation Rate } \\
\text { kg/capita/day }\end{array}$ \\
\hline $\begin{array}{l}\text { Cities with a population }<0.1 \text { million } \\
(8 \text { cities })\end{array}$ & $0.17-0.54$ \\
$\begin{array}{l}\text { Cities with a population of } 0.1-0.5 \\
\text { million }(11 \text { cities })\end{array}$ & $0.22-0.59$ \\
Cities with a population of $1-2$ million \\
$(16$ cities $)$ \\
$\begin{array}{l}\text { Cities with a population }>2 \text { million } \\
(13 \text { cities })\end{array}$ \\
\hline \hline
\end{tabular}

MSW composition at generation sources and collection points, determined on a wet weight basis, consists mainly of a large organic fraction (40-60\%), ash and fine earth (30-40\%), paper (3-6\%) and plastic, glass and metals (each less than $1 \%$ ). The $\mathrm{C} / \mathrm{N}$ ratio ranges between 20 and 30 , and the lower calorific value ranges between 800 and 1000 $\mathrm{kcal} / \mathrm{kg}$ [8]. The disposal methods may include open dumping, incineration, composting, landfilling and using it as refused derived fuel.

Disposal of kitchen wastes in open dumps causes the public health hazards and diseases such as malaria, cholera, typhoid. Inadequate management of wastes like uncontrolled dumping bears several adverse consequences. It not only leads to polluting surface and groundwater through leachate and further promotes the breeding of flies, mosquitoes, rats and other disease bearing vectors. Also, it emits unpleasant odor \& methane which is a major greenhouse gas contributing to global warming.

The techniques like incineration and pyrolysis are expensive and less efficient for recovering energy from the food wastes, owing to the fact that the food wastes contains a large amount of moisture content. Anaerobic digester will be an economical and viable option to serve the purpose of the project. Therefore, in this study, utilization of food waste for the production of biogas and design of the biodigester is carried out, along with the rate analysis, for the same.

The major goal of this study was to characterize the solid waste and find its potential to be recovered in the form of energy from the large amount of food waste generated. For this purpose a survey of campus kitchens was conducted by circulating a questionnaire will to collect the data of the daily food waste and the frequency of substituting the liquefied petroleum gas (LPG) cylinders

The characterization of the kitchen waste would consists of finding the basic parameters like moisture content, volatile matter and calorific value to check it's feasibility to be used for production of biogas in various climatic conditions.

\section{MATERIALS AND MethodS}

\section{A. Survey}

The survey for the Bhavan's Campus kitchens and the waste produced by the same was divided into two main parts:

a) A consideration of all the available canteens and kitchens, followed by a basic survey, which led to the selection of kitchens

b) Use of questionnaires to understand the actual amount of waste generated and the feasibility of utilising all the canteen kitchens for the project

Bhavan's campus encompasses the following colleges and hence, their canteens:

a) Bhavan's college of arts, commerce and science

b) Sardar Patel College of Engineering and Sardar Patel Institute of Technology

c) SP Jain Institute of Management and Research

d) Hansraj Morarji School and Raj Hans SchoolSubmit your manuscript electronically for review.

\section{B. The Questionnaire}

A questionnaire was designed for collecting information about waste generation in all the canteens. The questions included, were so as to get a basic idea about the two important qualities of the waste generated viz quantity and disposal.

Questionnaire for Canteen solid waste generation

Particulars Quantities

Canteen no. :

Source:

Name of owner:

Daily hours of operation:

Type(s) of waste generated:

Approximate quantity of daily waste:

Current method of disposal:

Location of disposal:

Time of disposal:

Current recovery from daily waste (if any):

Type of cooking fuel used:

Daily cooking fuel requirement:

Approximate daily expenditure:

The questionnaire gave the basic idea about the amount of waste generated and characterization of waste based on moisture content, organic matter and calorific value.

After giving due consideration, it was decided to use the waste generated from four main canteens of the campus:

a) Bhavan's college canteen

b) Sardar Patel Canteen

c) Sardar Patel hostel Mess

d) SP Jain hostel Mess

Once the sampling kitchens were ascertained, sampling was carried on during peak hours of solid waste collection from the kitchens during rainy season. An average sample of $1.5 \mathrm{~kg}$ of solid waste generated was collected and characterized to find the quality. The characterization of solid waste was done to by finding total moisture content (Standard Methods, APHA), organic matter (volatile matter, Standard methods, APHA) and calorific value (Parr oxygen bomb calorimeter) of solid waste 


\section{RESULTS AND DISCUSSION}

As per the questionnaire prepared the results obtained weekly sampling are depicted in Table III.

TABLE III: QUESTIONNAIRE RESULTS

\begin{tabular}{|c|c|c|c|c|}
\hline $\begin{array}{l}\text { Canteen } \\
\text { name }\end{array}$ & $\begin{array}{l}\text { Bhavan's } \\
\text { Canteen }\end{array}$ & $\begin{array}{l}\text { Sardar } \\
\text { Patel } \\
\text { Canteen }\end{array}$ & $\begin{array}{l}\text { Sardar } \\
\text { Patel } \\
\text { Mess }\end{array}$ & $\begin{array}{l}\text { SP Jain } \\
\text { Mess }\end{array}$ \\
\hline $\begin{array}{l}\text { SOURCE/ } \\
\text { Type of } \\
\text { Waste }\end{array}$ & $\begin{array}{l}\text { Mostly } \\
\text { Organic with } \\
\text { some plastic } \\
\text { and glass }\end{array}$ & $\begin{array}{c}\text { Food and } \\
\text { Plastic } \\
\text { Mostly } \\
\text { organic. }\end{array}$ & $\begin{array}{l}\text { Food and } \\
\text { peelings } \\
\text { (organic) }\end{array}$ & $\begin{array}{l}\text { Food }+ \\
\text { Plastic }\end{array}$ \\
\hline $\begin{array}{l}\text { Name of } \\
\text { owner }\end{array}$ & Santosh & Anna & & Santosh \\
\hline $\begin{array}{l}\text { Hours of } \\
\text { operation }\end{array}$ & 8 am to $6 \mathrm{pm}$ & $\begin{array}{c}7 \text { am to } 7: 30 \\
\text { pm }\end{array}$ & $\begin{array}{c}7 \text { am to } \\
2: 30 \mathrm{pm} \\
\text { and } 5 \mathrm{pm} \\
\text { to } 9: 30 \mathrm{pm}\end{array}$ & $\begin{array}{l}8 \mathrm{am} \text { to } \\
2: 30 \mathrm{pm} \\
\text { and } 8 \mathrm{pm} \\
\text { to } 11 \mathrm{pm}\end{array}$ \\
\hline $\begin{array}{l}\text { Approximate } \\
\text { quantity }\end{array}$ & $100 \mathrm{~kg}$ & $\begin{array}{c}3 \text { large } \\
\text { cans= } \\
\text { approx } 75 \\
\text { kg }\end{array}$ & $\begin{array}{c}2 \text { large } \\
\text { cans }= \\
\text { approx } 50 \\
\text { kg }\end{array}$ & $\begin{array}{c}1.5 \text { cans }= \\
\text { approx } 40 \\
\mathrm{~kg}\end{array}$ \\
\hline $\begin{array}{l}\text { Method of } \\
\text { disposal }\end{array}$ & \multicolumn{4}{|c|}{ Municipality Van picks from outside campus bin } \\
\hline $\begin{array}{l}\text { Location of } \\
\text { disposal }\end{array}$ & \multicolumn{4}{|c|}{ Outside Campus } \\
\hline $\begin{array}{l}\text { Time of } \\
\text { disposal } \\
\text { Current }\end{array}$ & \multicolumn{4}{|c|}{7 pm daily } \\
\hline $\begin{array}{l}\text { Recovery } \\
\text { from waste }\end{array}$ & \multicolumn{4}{|c|}{ Not applicable } \\
\hline Type of fuel & LPG & LPG & LPG & LPG \\
\hline $\begin{array}{l}\text { Daily fuel } \\
\text { requirement }\end{array}$ & $\begin{array}{c}2.5 \\
\text { commercial } \\
\text { cylinders }\end{array}$ & $\begin{array}{c}1.5 \\
\text { commercial } \\
\text { cylinders }\end{array}$ & $\begin{array}{c}2.5 \\
\text { cylinders }\end{array}$ & $\begin{array}{c}2 \\
\text { cylinders }\end{array}$ \\
\hline
\end{tabular}

The bucket sampling method was adopted for first sampling which is quite different from the truck load method [9]. As described in materials and methods characterization of waste collected from canteen was performed and the results are as depicted in table 4.

As observed the quantities of waste generated from various canteens and mess was different due to several reasons. Mess caters around 200 students living in a hostel twice a day amounting for per capital generation as (total waste/no of students). Whereas the Bhavan's and SP canteen caters for snacks for total no of students of 2000 amounting for waste generation as $0.1325 \mathrm{~kg}$ per capita per day.

It was observed that no proper disposal method is followed resulting into smell and fly nuisance in and around campus. The collection bins are open with spillage around the area.

The total consumption of LPG gas for the campus is 8.5 cylinders amounting to $120.7 \mathrm{~kg}$ and the total monthly requirement as $3621 \mathrm{~kg}$. Table IV gives the results of characterization of wastes from the various kitchens.

\begin{tabular}{lccc}
\multicolumn{4}{c}{ TABLE IV: QuESTIONNAIRE RESULTS } \\
\hline \hline $\begin{array}{c}\text { Moisture } \\
\text { Content (\%) }\end{array}$ & Ash (\%) & $\begin{array}{c}\text { Volatile } \\
\text { Matter (\%) }\end{array}$ \\
\hline Bhavan's & 66.8 & 8.43 & 91.6 \\
SPCE Mess & 76.4 & 23.3 & 76.7 \\
SPCE Canteen & 81.6 & 10.9 & 89.2 \\
SP Jain Mess & 76.6 & 19 & 81 \\
\hline \hline
\end{tabular}

\section{A. Moisture content}

As observed the moisture content of the waste varied from 65 to $80 \%$ as expected from the kitchen waste. It is comparable to the moisture content obtained by Hafid et al., 2011. This can be a potential problem if we derive energy in the form of steam as a huge amount of fuel would be wasted in drying the waste. Biogas is a better option as there is a requirement of moisture in $50 \%$.

\section{B. Ash Content}

Ash content of solid waste from the kitchens varied between $8-23 \%$ which is in the range of ash content expected in municipal solid waste (3-28\%) [10]

\section{Volatile Matter}

It was observed that the volatile matter varied from $80 \%$ to $92 \%$. This is comparable to the $92 \%$ of volatile matter content obtained from the kitchen waste from Burford, Shropshire [11]. Wastes with high volatile matter content produce more biogas if digested properly, as it is the organic matter that produces biogas.

\section{Calorific Value}

Following table indicates different values of calorific value obtained by experimental method as well as by analysis using the equations [9]:

$$
\begin{gathered}
\mathrm{CV}=356.248 \mathrm{VM}-6998.497(\mathrm{~kJ} / \mathrm{kg}) \\
\mathrm{CV}=356.047 \mathrm{VM}-118.035 \mathrm{FC}-5600.613(\mathrm{~kJ} / \mathrm{kg}) \\
\text { Benton: } \mathrm{CV}=4.2 *(44.75 \mathrm{VM}-5.85 \mathrm{~W}+21.2)
\end{gathered}
$$

where,

$\mathrm{CV}$ - calorific value in $\mathrm{kJ} / \mathrm{kg}$

VM- Volatile Matter in percentage

FC- Fixed Carbon content

W- Moisture Content

The calorific values for various kitchens were found out using the equations and are depicted in Fig. 1.

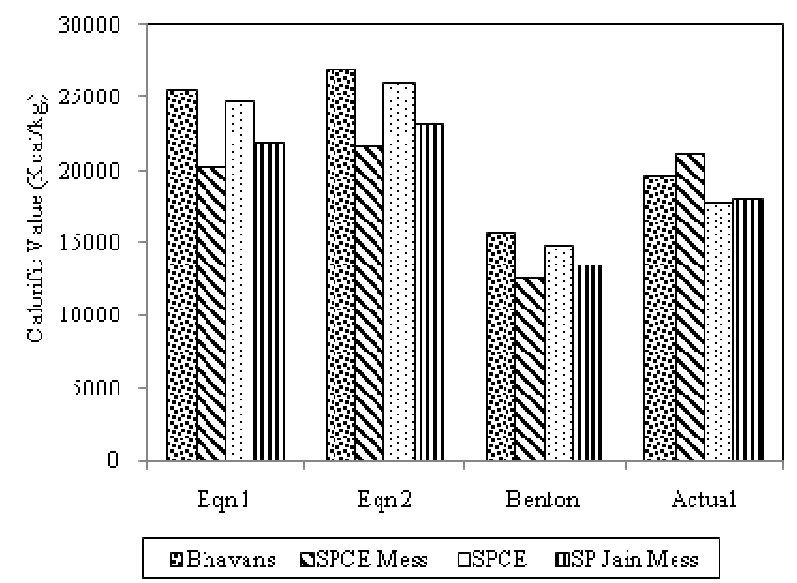

Fig. 1. Calorific value for various wastes in different kitchens in Bhavan's campus

On the basis of the experimental values and the values obtained using the above mentioned equations, as well considering the factors such as diurnal variation of food constituents, humidity and temperature, we infer that the possible calorific value for this set of kitchen wastes vary 
from $15000-25000 \mathrm{~kJ} / \mathrm{kg}$. The above results were compared with those obtained in the research paper by Kalantaifard and Yang (2011). They obtained a calorific value of $23000 \mathrm{~kJ} / \mathrm{kg}$. Thus, we conclude that the calorific values obtained in our project, are in a considerable range.

On the basis of the above results, we shall compute the volume of the gas required, and the discharge of waste sludge, anaerobic digester will be designed to fulfill the purpose of this entire project. Currently, LPG commercial cylinders are used at a rate of $8.5 /$ day $(2650 \mathrm{~kJ} / \mathrm{kg}$ approx.), combining all the 4 locations. Therefore, as a result of the above project, the conventional fuel sources will be replaced by the biogas fuel source; thereby improving the efficiency of the fuel as well as the management of waste will be carried out in an effective manner.

\section{CONCLUSION}

India's energy problems have made the need to turn towards waste-to-energy technologies extremely important, especially because landfills in India's urban centres are fast nearing the limits of their capacity.

The characterization of kitchen waste collected from four canteens in the Bhavan's campus, the average moisture content of the samples was found to be around $75 \%$. High moisture content makes thermal recovery from solid waste uneconomical as considerable fuel is used up by the latent moisture in the solid waste. Anaerobic digestion, which requires high moisture content for the sustenance of the methane bacteria, was the preferred alternative for energy recovery from organic waste in the Bhavan's campus. A higher volatile matter content leads to a better biogas yield. The test samples contained an average of $85 \%$ of volatile matter, thus strengthening the case for the adoption of anaerobic digestion in the Bhavan's campus.

\section{ACKNOWLEDGMENT}

The authors would like to acknowledge Centre for Environmental Sc. And Engg. for the usage of bomb calorimeter and to TEQIP- Phase II grant by DTE, Maharashtra for sponsorship.

\section{REFERENCES}

[1] P. Alonso and Themelis, "Generation and Disposition of Municipal Solid Waste in Mexico and Potential for Improving Waste Management in Toluca Municipality," Waste-to-Energy Research and Technology Council (WTERT), 2011.

[2] Hoornweg and B. Tata, "What A Waste - A Global Review of Solid Waste Management," Urban Development Series, World Bank, 2012.

[3] The World Bank Report titled, "How we Classify Countries," in Little Data Book, Urban Development Series, 2009.

[4] Recycling Initiatives- Durban Metro. [Online]. Available: http://www.ceroi.net, 1999.

[5] A. Bandhu, Government of Uttar Pradesh, "Detailed Project Report for Solid Waste Management in Agra, Uttar Pradesh," RCUES, September 2008.

[6] National Bio-Energy Board, National Master Plan for Development of Waste to Energy in India, MWH Publication, pp. 1-10, 2009.

[7] JNNURM 2005 Report for Urban Development. (2005) [Online]. Available: www.karmayog.com

[8] M. Sharholy, K. Ahmed, G. Mahmood, and R. C. Trivedi, "Municipal solid waste management in Indian cities - A review," Waste Management, vol. 28, no. 2, pp. 459-467, 2008.

[9] A. Kalantaifard and G. Yang, "Energy potential from municipal solid waste in Tanjung Langsat landfill, Johor, Malaysia," International

Journal of Engineering Science and Technology (IJEST), vol. 3, no. 12, pp. 8560-8568, 2011.

[10] G. Tchobanoglous, Solid wastes, McGraw-Hill, 1977.

[11] C. Banks, M. Chesshire, and A. Stringfellow, "A pilot-scale comparison of mesophilic and thermophilic digestion of source segregated domestic food waste," Water Science and Technology vol. 58, no. 7, pp. 1475-1481, 2008.

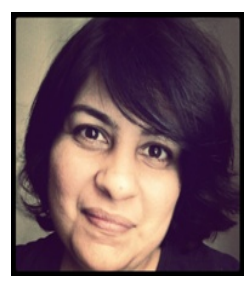

Hansa Jeswani was born in Ajmer, Rajasthan. She completed her Ph. D in Environmental Engineering in Centre for Environmental Sc. And Engg., Indian Institute of Technology, Bombay, India. She completed her Master's in Environmental Engineering and Bachelor's in Civil Engineering from Faculty of Engineering and technology, Maharaja Sayaji Rao University Baroda, India.

She has 10 years of experience in academic field and a year's experience in a consultant firm. She is currently Senior Asst. Professor in Sardar Patel College of Engineering. She worked as an environmental engineer in Paramount Pollution Control Limited for a year. Over the past decade, her research is related to areas of waste, wastewater management and incorporating these technologies in sustainable structures. She has wide variety of publication in international Journals, international and national conferences. Her research involves quantifying data related to municipal solid waste, understanding the nuances of impacts and taking corrective management action for the same which may involve a series of treatments or a single biological unit. Another aspect of her research is using waste and wastewater treatment technologies in sustainable buildings in an economically viable manner.

Dr. Hansa is a member of CBEES, ISTE, AWMA, IWA and IEA. She has won the award for meritorious student in Master's of Engineering. She has worked as a mentor of International award winning team of Tower of Babylon.

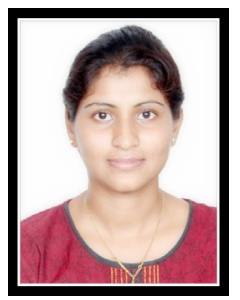

Vasavi Cheernam was born in Chandrapur, Maharashtra, India. She is currently pursuing Bachelor's in Civil Engineering from Sardar Patel College of Engineering, Mumbai, India.

She is an intern from Bharat Petroleum Corporation Ltd- Kochi Refineries and Coal India Ltd. She has keen interest in the subject of Environmental Engineering, as both her internships gave exposure on the same.

Apart from academics, she is an active participant in extracurricular activities. She holds various certificates as National Cadet Corp, Ladies Representative - Student Council, SPCE etc. She volunteered for various Non Governmental Organizations due to her interest in social service.

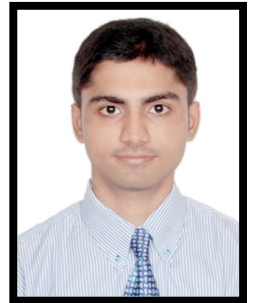

solutions.

In his under-grad years, he has held several responsible positions such as the 'Head of Public Relations' at 'Nirmaan 2011', the techfest of Sardar Patel College. He had also won the First Prize in the college, for the subject of 'Communication Skills' in First Year of Bachelor's Course. He has also been learning the Indian Flute since February 2010, under the guidance of a professional flautist.

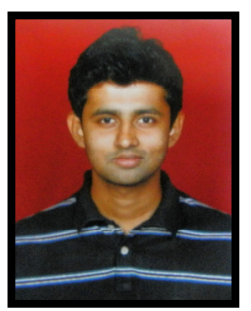

Adwait Apte is currently a final-year Civil Engineering student at the Sardar Patel College of Engineering in Mumbai, Maharashtra, India. Right from school, he has always been involved with environmental causes.

He aspires to pursue a career in renewable energy and will begin his Master's program in fall of this year. He was instrumental in the establishment of the 'Green Club' in his college. He worked on a project to promote energy efficiency on college campuses in Pune, Maharashtra as an intern with Terre Policy Centre. 


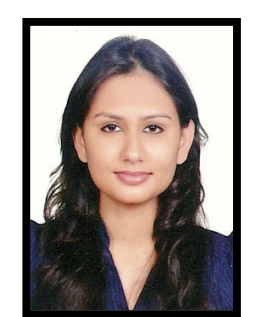

Parineeta Kashikar was born in Belgaum, Karnataka. She is currently pursuing her Bachelor's degree in Civil Engineering at Sardar Patel College of Engineering, Mumbai.

She has been an intern at Aquachem Enviro Engineers Pvt. Ltd, Mumbai where she received training in the execution of water treatment projects, and in the testing of domestic and industrial effluents.

She is interested in pursuing a career in research in the field of environmental engineering, and has presented papers on the same at various national and international conferences. She has been published for her award winning essay on the "Future of Energy in India." She is a member of ASCE.

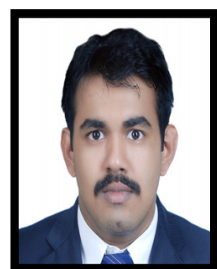

Madhusudan Kamat was born in Mumbai. He is currently pursuing his Bachelor's degree in Civil Engineering at Sardar Patel College of Engineering, Mumbai.

He is currently working on a startup project for the development of renewable fuel for an Indian firm. His ambition is to ensure the use of renewable resources all over.

He has written a paper researching the technology used in the green city of Masdar in Dubai. He has also worked on a paper research, 'The use of E-Waste in concrete'. He has also worked as an intern with Larsen and Toubro at their Metro site. 